\title{
Evaluasi Kegiatan Sosialisasi Produk Impor Halal dan Nonhalal bagi Siswa Madrasah Aliyah Persis 24 Rancaekek Bandung
}

\section{(The Evaluation of the Socialization Activities of Halal and Non-halal Import Product for the Students of Madrasah Aliyah Persis 24 Rancaekek Bandung)}

\author{
Akim*, Chandra Purnama, Neneng Konety, Febriani Amalina Shalihah \\ Program Studi Hubungan Internasional, Fakultas Ilmu Sosial dan Ilmu Politik, Universitas Padjadjaran, \\ Jl. Raya Bandung Sumedang Km. 21, Hegarmanah, Jatinangor, Sumedang 45363. \\ *Penulis Korespondensi: akim@unpad.ac.id \\ Diterima Oktober 2019/Disetujui Maret 2020
}

\begin{abstract}
ABSTRAK
Keberadaan Indonesia sebagai negara dengan jumlah masyarakat muslim terbesar di dunia menjadi daya pikat bagi para produsen luar negeri, ditambah dengan pereferensi masyarakat yang relatif lebih suka dengan produk impor mengakibatkan pasar domestik Indonesia dibanjiri dengan produk impor. Kondisi ini menjadi sesuatu yang sedikit membahayakan untuk konsumen muslim ketika dikaitkan dengan belum kuatnya kesadaran halal masyarakat Indonesia sehingga diperlukan kegiatan penyadaran masyarakat yang salah satunya berupa kegiatan sosialisasi. Artikel ini bertujuan untuk mengevaluasi kegiatan sosialisasi yang dilakukan di kalangan siswa Madrasah Aliyah di Rancaekek Bandung. Kegiatan sosialisasi dilakukan dengan menggunakan metode seminar berupa ceramah dengan tanya jawab dan metode simulasi berupa latihan simulasi (exercise simulation). Sementara itu, evaluasi kegiatan sosialisasi dilakukan dengan melakukan tes sebelum (pre-test) dan sesudah (post-test) sosialisasi dengan bantuan IBM SPSS versi 21 untuk mengukur pengaruh pemberian sosialisasi terhadap pengetahuan siswa MA Persis 24 Rancaekek terkait kehalalan produk impor. Dari hasil tes yang diperoleh, dapat disimpulkan bahwa kegiatan sosialisasi yang dilakukan mampu meningkatkan pengetahuan siswa MA Persis Rancaekek terkait pentingnya kehalalan suatu produk impor yang beredar di masyarakat.
\end{abstract}

Kata kunci: gaya hidup halal, madrasah aliyah, produk impor, sosialisasi

\begin{abstract}
The existence of Indonesia as a country with the largest number of Muslim societies in the world is an allure for foreign producers, coupled with the preference of people who are relatively more interested in imported products resulting in Indonesia's domestic market being flooded with imported products. This condition is a bit dangerous for Muslim consumers when it is associated with the lack of halal awareness in Indonesian society so that the activities of community awareness are needed, one of which is in the form of socialization activities. This article aims to evaluate the socialization activities carried out among Madrasah Aliyah (Islamic Senior High School) students in Rancaekek Bandung. The socialization activities are carried out through the seminar method in the form of lectures with questions, answers, simulation methods in the form of simulation exercises. Meanwhile, the evaluation of the socialization activities was carried out by conducting pre-test and post-test with the help of IBM SPSS version 21 to measure the effect of socialization on the knowledge of the students of Madrasah Aliyah Persis 24 Rancaekek related to the halal of imported products. From the test results obtained, it can be concluded that the socialization activities carried out succeeded in increasing the knowledge of the students of Madrasah Aliyah Persis Rancaekek regarding the importance of the halal status of imported products circulating in the community.
\end{abstract}

Keywords: halal lifestyle, madrasah aliyah, imported products, socialization

\section{PENDAHULUAN}

Industri halal saat ini telah menjadi industri yang sangat berkembang pesat di dunia. Dilihat menggunakan perspektif bisnis, pasar halal tidak diragukan lagi menawarkan berbagai peluang menarik. Nilai-nilai dan prinsip-prinsip yang dibawa dalam pasar halal membentuk adanya paradigma komersial yang baru. Saat ini industri halal tidak hanya berkembang dalam sektor 
makanan dan minuman, yang merupakan sektor utama, namun juga meluas ke sektor-sektor lainnya seperti sektor farmasi, kosmetik, dan perawatan pribadi. Hal ini didorong oleh adanya peningkatan kesadaran konsumen dan para pelaku bisnis terhadap peluang pasar halal (International Trade Centre 2015). Salah satu negara yang memiliki permintaan akan produk impor halal di dunia adalah Indonesia.

Menurut Pusat Data Kementerian Agama RI, ada sebanyak 86,69 persen dari 266.534 .836 jiwa penduduk Indonesia yang menjadi pemeluk agama Islam (Kementerian Agama 2020). Banyaknya penduduk muslim di Indonesia menjadikan Indonesia sebagai negara dengan jumlah penduduk muslim terbesar di dunia sebagaimana ditegaskan oleh Presiden Joko Widodo (Berty 2019). Besarnya jumlah penduduk muslim di Indonesia berpotensi menjadikan Indonesia sebagai negara produsen sekaligus konsumen halal terbesar di dunia. Kenyataannya, kondisi tersebut justru cenderung tidak menjadikan Indonesia sebagai negara produsen halal dunia tetapi sebaliknya menjadikan Indonesia sebagai pangsa pasar produk halal dunia (Nirwandar 2019). Sebagaimana dinyatakan oleh Wakil Presiden Indonesia, Ma'ruf Amin, bahwa Indonesia merupakan negara importir terbesar produk halal di dunia (Hakim 2019). Hal ini merupakan tantangan serius bagi para produsen lokal Indonesia untuk meningkatan daya saing produknya agar mampu berkompetisi dengan produk halal impor.

Hal lainnya yang turut menjadi masalah adalah keberadaan produk impor nonhalal yang meliputi berbagai jenis kategori produk seperti kosmetika, suplemen, obat-obatan serta makanan dan minuman. Banjirnya produk impor nonhalal di masyarakat mengakibatkan kerugian bagi konsumen muslim. Sayangnya, tidak semua konsumen muslim di Indonesia memiliki pengetahuan dan kesadaran tentang keberadaan produk impor nonhalal. Padahal dalam beberapa tahun terakhir, peredaran produk impor nonhalal telah masuk dan menyebar ke pasar domestik di berbagai kota di Indonesia. Salah satu contoh, Pemerintah Sukabumi menemukan produk pangan impor nonhalal seperti mi instan, sosis, keju, dan minuman telah beredar luas di beberapa supermarket di Sukabumi (Ramadhan 2016). Kemudian muncul juga kasus beredarnya 15 produk makanan impor berlabel halal palsu di beberapa kota besar di Indonesia termasuk di Kota Bandung (Handayani 2016). Selanjutnya, Badan Pengawas Obat dan Makanan (BPOM) pernah membuat surat perintah penarikan produk mi instan asal Korea dengan merek tertentu dari peredaran pasar domestik Indonesia karena mengandung DNA babi, sementara pada kemasan produk tersebut tidak mencantumkan peringatan mengandung babi (BPOM 2017). Salah satu lembaga advokasi halal yaitu, Indonesia Halal Watch (IHC) menyebutkan ada 11 produk makanan kemasan impor yang tidak memiliki label halal tetapi beredar di tengah masyarakat Indonesia. Selain itu, IHC juga menyebutkan ada 17 produk makanan impor lain yang memiliki label halal tetapi diragukan kehalalannya (Agrifood 2018). Merebaknya berbagai produk impor nonhalal di tengah masyarakat Indonesia menimbulkan kerugian tidak hanya bagi produsen lokal tetapi juga bagi konsumen muslim di Indonesia.

Pemberian informasi dan pengetahuan terhadap konsumen muslim Indonesia sangat diperlukan dalam rangka membangun kesadaran masyarakat untuk mengurangi konsumsi produk impor dan terhindar dari penggunaan produk impor nonhalal. Salah satu upaya penyebaran informasi dan pengetahuan yang dapat dilakukan, yaitu melalui kegiatan sosialisasi. Idealnya kegiatan sosialisasi dapat menyasar berbagai kalangan masyarakat, akan tetapi dalam kesempatan kali ini penulis memilih untuk melakukan sosialisasi dikalangan generasi milenial. Pertimbangan dipilihnya generasi milenial sebagai target sasaran sosialisasi karena jumlah generasi milenial di Indonesia cukup besar, yakni $33,75 \%$ dari keseluruhan jumlah penduduk Indonesia. Selain itu, generasi milenial juga merupakan generasi yang secara estafet kepemimpinan bangsa akan berperan sebagai generasi penerus dalam beberapa tahun ke depan menggantikan generasi sebelumnya(BPS 2018).

Telah banyak artikel yang membahas mengenai pengetahuan masyarakat terhadap produk halal. Beberapa di antaranya adalah artikel yang ditulis oleh Yasid et al. (2016); Nusran et al. (2018); dan Budiman (2019). Artikel pertama dan kedua menjelaskan tentang faktor-faktor yang memengaruhi halal awareness dan pentingnya usaha peningkatannya sedangkan artikel terakhir membahas tentang halal awareness sebagai salah satu pertimbangan konsumen dalam membeli produk. Selain halal awareness, artikel yang membahas mengenai impor produk halal dan nonhalal di Indonesia juga telah banyak diterbitkan, misalnya oleh Hosanna \& Nugroho (2018); Ratanamaneichat \& 
Rakkarn (2013); dan Revin et al. (2017). Ketiga artikel tersebut menjadi acuan penulis dalam memahami tentang impor produk di Indonesia dan usaha untuk menjamin status kehalalannya. Perbedaan artikel ini dengan artikel-artikel sebelumnya terletak pada fokus dan lokus penelitian. Fokus penelitian dalam artikel ini terletak pada pengetahuan siswa terhadap produk impor halal dan nonhalal, dengan lokus kajian di Kabupaten Bandung, Jawa Barat.

Pada kurun waktu Juni-Agustus 2019, Universitas Padjadjaran menyelenggarakan kegiatan kolaborasi antara kegiatan Tridharma Perguruan Tinggi berupa Pengabdian Pada Masyarakat (PPM) yang dilakukan oleh dosen dengan kegiatan Kuliah Kerja Nyata Mahasiswa (KKNM) yang dilakukan oleh mahasiswa. Kegiatan kolaborasi tersebut bernama Kuliah Kerja Nyata Mahasiswa-Pengabdian pada Masyarakat Dosen Integratif (KKNM-PPMD Integratif). Dalam rangka kegiatan PPMD Integratif tersebut penulis melakukan kegiatan sosialisasi dengan judul: sosialisasi produk impor yang halal dan nonhalal bagi siswa Madrasah Aliyah Persis 24 Rancaekek Bandung. Artikel ini ditulis dengan tujuan untuk melakukan evaluasi kegiatan sosialisasi produk impor yang halal dan nonhalal yang telah dilakukan terhadap siswa MA Persis 24 Rancaekek Bandung. Evaluasi pelaksanaan sosialisasi ini diharapkan dapat mengetahui tingkat keberhasilan dari program sosialisasi yang telah diselenggarakan serta berbagai kendala yang terjadi dilapangan. Rumusan masalah dalam artikel ini adalah "Bagaimana pengaruh kegiatan sosialisasi produk impor yang halal dan nonhalal terhadap perubahan pengetahuan siswa Madrasah Aliyah Persis 24 Rancaekek Bandung"?

\section{METODE PELAKSANAAN KEGIATAN}

\section{Lokasi Kegiatan dan Partisipan Kegiatan}

Kegiatan sosalisasi dilaksanakan pada tanggal 29 Juni 2019 di MA Persis 24 yang beralamat di Jalan Cikijing Km 1,5, Desa Linggar, Kecamatan Rancaekek, Kabupaten Bandung, Jawa Barat. Kegiatan ini melibatkan beberapa pihak terkait, yaitu: 1) Pimpinan MA Persis 24, yang berperan dalam memberikan izin untuk pelaksanaan sosialisasi kegiatan KKNM-PPMD Integratif Unpad; 2) Siswa kelas XII IPA dan IPS MA Persis 24 sebanyak 44 orang, sebagai partisipan kegiatan; 3) Tim Dosen Unpad, sebanyak tiga orang sebagai narasumber kegiatan; dan 4) Mahasiswa peserta
KKNM Unpad sebagai panitia pelaksana dan fasilitator kegiatan.

Adapun lokus sosialisasi yang dipilih adalah daerah Rancaekek Bandung, Jawa Barat. Daerah ini dipilih dengan pertimbangan bahwa Kecamatan Rancaekek merupakan daerah yang strategis dengan pertumbuhan ekonomi yang begitu pesat di wilayah Bandung Timur. Hal ini dikarenakan Rancaekek merupakan salah satu pusat kawasan industri tekstil di Jawa Barat dan letaknya yang strategis karena dilewati jalan nasional antar kota dan antar-provinsi yang menghubungkan kota-kota di Jawa Barat dengan Jawa Tengah serta Rancaekek juga berbatasan langsung dengan Kota Pendidikan, Jatinangor, Sumedang. Adanya berbagai kemajuan ekonomi dan letaknya yang strategis tersebut, maka wilayah Rancaekek berpotensi menjadi salah satu daerah penyebaran produk impor nonhalal di Jawa Barat. Menurut data dari Kementerian Agama (2020), Jawa Barat merupakan provinsi dengan jumlah muslim terbesar di Indonesia, yakni 44.374.684 jiwa. Dengan berbagai pertimbangan tersebut di atas, penulis memilih salah satu MA yang ada di Rancaekek Bandung, yakni MA Persis 24, sebagai lokasi kegiatan sosialisasi.

Pemilihan siswa yang duduk di kelas XII MA rancaekek karena siswa kelas XII secara usia merupakan peralihan antara usia anak-anak ke dewasa, 17-18 tahun, dan secara pendidikan berada pada level tertinggi untuk kategori pendidikan menengah. Dengan demikian, siswa kelas XII dianggap secara usia sudah masuk kategori dewasa dan telah memiliki bekal pengetahuan yang cukup untuk mampu berpikir secara rasional. Kemudian, penulis juga menjatuhkan pilihan pada Madrasah Aliyah (MA) sebagai sekolah yang menjadi target sosialisasi dengan pertimbangan bahwa sekolah MA merupakan sekolah berbasis keagamaan sehingga memiliki kepentingan dan kesesuaian dengan materi sosialisasi yang akan disampaikan. Selain itu, siswa MA secara umum memiliki bekal pengetahuan agama Islam yang lebih baik dibandingkan siswa sekolah umum sehingga diharapkan akan lebih memudahkan siswa dalam menyerap materi sosialisasi.

\section{Alat dan Bahan}

Alat yang digunakan dalam kegiatan sosialisasi ini adalah slide presentasi microsoft powerpoint yang dilengkapi dengan seperangkat LCD projector dan pengeras suara. Selain itu, sosialisasi juga menggunakan smartphone yang 
sudah menginstal aplikasi halal MUI yang tersedia di Playstore/App Store untuk melakukan simulasi bagaimana cara mengetahui kehalalan suatu produk. Koneksi internet dilakukan dengan menggunakan paket quota dari penyedia jaringan internet. Tim fasilitator juga menyediakan bahan latihan simulasi berupa beberapa kemasan produk untuk dicek dengan menggunakan aplikasi halal MUI. Alasan pememilihan aplikasi "halal MUI" sebagai aplikasi untuk melakukan latihan simulasi pengecekan produk halal adalah pertama, aplikasi halal MUI merupakan aplikasi resmi yang dikeluarkan oleh MUI. Kedua, MUI/LPPOM MUI merupakan satu-satunya lembaga resmi sertifikasi halal di Indonesia pada waktu kegiatan ini dilakukan, mengingat UU No. 33 Tahun 2014 tentang Jaminan Produk Halal baru berlaku secara efektif pada 17 Oktober 2019.

\section{Metode Pelaksanaan}

Kegiatan sosialisasi dilakuan dengan menggunakan dua metode, yakni metode seminar dan simulasi. Bentuk metode seminar yang dipilih adalah ceramah dengan tanya jawab. Sedangkan bentuk simulasi yang digunakan adalah latihan simulasi (simulation exercise). Kedua metode ini disampaikan secara bertahap. Tahap pertama sosialisasi dilakukan dengan menggunakan metode seminar dalam bentuk ceramah dengan tanya jawab. Penggunaan metode ceramah dengan tanya jawab dimaksudkan agar siswa memiliki pengetahuan dan kesadaran tentang keberadaan produk impor halal dan nonhalal di masyarakat Indonesia. Kemudian setelah metode pertama selesai, sosialisasi dilanjutkan dengan menggunakan metode yang kedua, yaitu latihan simulasi. Metode latihan simulasi dengan menggunakan smartphone dilakukan dengan alasan bahwa siswa Madrasah Aliyah merupakan kelompok remaja yang telah memiliki akses untuk menggunakan smartphone dalam kehidupan sehari-hari.

\section{Metode Pengumpulan dan Pengolahan Data}

Metode pengumpulan data dilakukan dengan bantuan instrumen berupa kuesioner yang dibagikan kepada siswa MA Persis 24 Rancaekek yang menjadi peserta kegiatan sosialisasi. Jumlah pertanyaan yang diajukan dalam kuesioner berjumlah 22 pertanyaan yang terbagi dalam beberapa klaster. Adapun jumlah siswa MA Persis 24 Rancaekek yang menjadi peserta kegiatan sosialisasi adalah sebanyak 44 orang yang seluruhnya berasal dari siswa kelas XII.
Jumlah 44 orang siswa ini sepenuhnya ditentukan oleh kesiapan, daya tampung ruangan, dan izin yang diberikan oleh pihak sekolah kepada para siswa untuk mengikuti kegiatan sosialisasi dengan penekanan pada perbedaan kategori kelas siswa, yaitu kelas IPA dan IPS. Para siswa yang menjadi peserta sosialisasi diberikan pretest terlebih dahulu sebelum mengikuti kegiatan sosialisasi berupa ceramah dan simulasi yang disampaikan oleh tim sosialisasi. Kemudian setelah sosialisasi selesai dilakukan, para siswa MA Persis 24 Rancaekek yang menjadi peserta sosialisasi diberikan post-test untuk melihat perubahan pengetahuan mereka mengenai produk impor yang halal dan nonhalal. Adapun metode pengolahan data dilakukan dengan menggunakan Paired Sample Test dengan tingkat signifikasi sebesar 5\%. Pengolahan data ini dilakukan dengan menggunakan software IBM SPSS versi 21.

\section{HASIL DAN PEMBAHASAN}

Artikel ini merupakan luaran dari kegiatan PPMD yang dalam pelaksanaannya terintegrasi dengan kegiatan KKNM, Universitas Padjadjaran yang dikenal dengan istilah KKNM-PPMD Integratif Unpad. Pelaksanaan kegiatan ini sepenuhnya dibiayai oleh Unpad melalui mekanisme Hibah Internal Unpad (HIU) 2019. Secara umum kegiatan sosialiasi dilakukan dengan rangkaian kegiatan sebagai berikut:

\section{Tahapan Persiapan dan Pre-test}

Tahapan pertama dalam pelaksanaan KKNMPPMD Integratif diawali dengan tahap persiapan berupa pembekalan yang diberikan oleh Dosen Pembimbing Lapangan (DPL) pada tanggal 27 Mei 2019. Pembekalan KKN ini dilakukan agar mahasiswa dapat mengerti maksud, tujuan, dan mekanisme pelaksanaan KKNM-PPMD Integratif serta agar mahasiswa mengetahui dan memahami tentang apa itu halal dan bagaimana suatu produk dapat diklaim halal dan nonhalal.

Halal berasal dari bahasa Arab yang artinya "ibahah" atau sesuatu yang diizinkan untuk dikonsumsi menurut ketentuan dalam ajaran Islam. Adapun dasar hukum dari boleh atau tidaknya seorang muslim mengkonsumsi suatu produk tentu saja harus berasal dari sumber hukum Islam, yaitu Al-Qur'an, Hadist, dan Ijtihad (konsensus ulama) (Salehudin 2010). Pada perkembangan kontemporer, konsep halal ini tidak hanya dikenal pada masyarakat muslim 
saja, tetapi juga mulai diterima oleh masyarakat nonmuslim yang penerapannya meluas tidak hanya pada produk makanan dan minuman melainkan juga pada beberapa produk lainnya seperti obat-obatan, kosmetika, hotel, pariwisata, dan sebagainya(Lada et al. 2009).

Lawan kata halal adalah haram yang berarti mencegah, mencabut, terlarang atau melanggar hukum. Artinya jika suatu produk dimasukkan dalam kategori haram, maka produk tersebut terlarang untuk dikonsumsi oleh umat Islam. Kata halal dan haram telah dikenal diseluruh dunia sejalan dengan penyebaran umat Islam dan penggunaan kedua kata tersebut dalam kehidupan sehari-hari. Dalam Al-Quran Surat AlBaqarah ayat 168 telah dinyatakan dengan jelas bahwa: "Hai sekalian manusia, makanlah yang halal lagi baik dari apa yang terdapat di bumi, dan janganlah kamu mengikuti langkah-langkah setan, karena sesungguhnya setan ini musuh yang nyata bagimu" (Salehudin 2010). Selanjutnya Robin 2004 dalam Baharuddin et al. (2015) menjelaskan bahwa seruan kepada manusia dalam ayat tersebut menegaskan bahwa isu halal tidak hanya ditujukan untuk Muslim saja, namun juga untuk semua orang. Nilai-nilai dalam halal tidak ekslusif ditujukan kepada Muslim untuk keuntungannya sendiri, misalnya pada makanan halal yang dalam syarat-syarat halal harus disiapkan dengan cara yang paling higienis di mana ini juga menjadi salah satu standar keamanan pangan internasional. Halal sendiri memiliki kata lain yang saling berdampingan, yakni Toyyiban, yang artinya bersih dan sehat di mana berarti melambangkan kebersihan, keamanan, dan kualitas makanan yang dikonsumsi oleh umat Islam. Kebersihan, bebas dari kontaminasi, dan sehat yang merupakan syarat-syarat dalam makanan halal telah menjadi daya tarik bagi orang-orang nonmuslim, sehingga produk halal cepat mendapatkan pengakuan dari dunia sebagai tolak ukur keamanan dan kejaminan kualitas suatu produk. Produk dengan sertifikasi halal diterima dengan sangat baik oleh konsumen dari semua kalangan, baik muslim maupun nonmuslim. Hal ini dikarenakan bahwa halal mengandung banyak nilai universal dalam kehidupan, misalnya keselamatan, kesejahteraan hewan, keadilan sosial, dan lingkungan yang berkelanjutan (Baharuddin et al. 2015).

Setelah pembekalan dilaksanakan kegiatan selanjutnya adalah kunjungan ke sekolah. Kunjungan ke sekolah MA Persis 24 Rancaekek ini dilakukan untuk mencari informasi secara langsung mengenai sekolah tersebut dan informasi waktu sekolah mulai aktif kembali setelah libur semester genap. Setelah mendapat informasi yang cukup untuk menjadi referensi dosen dan mahasiswa melakukan perencanaan kegiatan beberapa kali di bulan Juli. Pada beberapa pertemuan ini, dosen dan mahasiswa merencanakan dan mempersiapkan kegiatan sosialisasi yang akan dilaksanakan. Pada tanggal 8 Juli mahasiswa KKNM dan DPL mengunjungi MA Persis 24 Rancaekek untuk bersilaturahmi dengan pihak sekolah sekaligus menyerahkan surat pengantar izin pelaksanaan KKNM-PPMD Integratif serta meminta kesediaan dari pihak sekolah mengenai kegiatan sosialisasi yang akan diselenggarakan.

Sebelum pelaksanaan kegiatan sosialisasi, terlebih dahulu dilakukan kegiatan pre-test terhadap siswa MA Persis 24 Rancaekek yang menjadi peserta sosialisasi. Masing-masing siswa peserta sosialisasi diberikan satu lembar kertas kuesioner dan satu balpoin untuk mengisi kuesioner. Kemudian fasilitator membacakan instruksi pengisian kuesioner dan memberikan jangka waktu pengisian kuesioner selama 30 menit. Pengisian kuesioner pre-test ini dilakukan untuk mengetahui tingkat pengetahuan awal dari para siswa peserta sosialisasi mengenai kehalalan produk impor. Hasil pre-test yang dilakukan terhadap siswa peserta sosialisasi tercermin dalam Tabel 1.

\section{Pelaksanaan Kegiatan Sosialisasi}

Kegiatan sosialisasi dilakukan pada tanggal 29 Juli 2019 oleh dosen dan mahasiswa dengan menggunakan dua metode yaitu metode seminar berupa ceramah dengan tanya jawab dan metode simulasi berupa latihan simulasi (exercise simulation). Dalam metode cermah, terlebih dahulu dilakukan penyampaian materi mengenai kehalalan suatu produk impor ditinjau dari berbagai aspek keilmuan seperti ilmu agama, kesehatan, hukum, peternakan, dan perdagangan internasional oleh tim dosen. Sehingga, diharapkan peserta sosialisasi dapat memperoleh pengetahuan mengenai produk impor halal dan nonhalal secara lebih komprehensif. Ceramah dilakukan selama kurang lebih dua jam yang disampaikan tim dosen. Setelah ceramah dilaksanakan, acara dilanjutkan dengan kegiatan tanya jawab dengan memberikan kesempatan kepada siswa untuk menanyakan hal-hal yang dianggap belum jelas dan memerlukan penjelasan tambahan. Tanya jawab dilakukan dengan durasi 30 menit. Pelaksanaan kegiatan sosialisasi produk impor yang halal dan non halal 
Tabel 1 Hasil pre-test

\begin{tabular}{|c|c|c|c|}
\hline \multirow[b]{2}{*}{ Pertanyaan dan pernyataan } & \multicolumn{3}{|c|}{ Pre-test } \\
\hline & $\begin{array}{l}\text { Ya } \\
(\%)\end{array}$ & $\begin{array}{l}\text { Ragu- } \\
\text { ragu }(\%)\end{array}$ & $\begin{array}{c}\text { Tidak } \\
(\%)\end{array}$ \\
\hline Pengetahuan mengenai halal dalam segi agama & 60 & 8 & 32 \\
\hline $\begin{array}{l}\text { Apakah di dalam QS. Al-Baqarah: } 168 \text { menjelaskan tentang perintah Allah } \\
\text { untuk mengonsumsi makanan halal dan baik? }\end{array}$ & 96 & 2 & 2 \\
\hline $\begin{array}{l}\text { Apakah semua produk yang tidak mengandung babi sudah pasti kehalalannya } \\
\text { dalam pandangan Islam? }\end{array}$ & 25 & 14 & 61 \\
\hline Pengetahuan mengenai kehalalan suatu produk impor & 30 & 30 & 40 \\
\hline $\begin{array}{l}\text { Apakah anda tahu ada banyak produk impor yang mengandung unsur } \\
\text { turunan dari babi? }\end{array}$ & 64 & 20 & 16 \\
\hline $\begin{array}{l}\text { Apakah anda mengetahui daging impor yang ASUH (Aman, sehat, utuh, dan } \\
\text { halal)? }\end{array}$ & 14 & 20 & 66 \\
\hline Apakah anda dapat membedakan antara daging impor yang halal dan haram? & 16 & 18 & 66 \\
\hline $\begin{array}{l}\text { Apakah anda tahu adanya kemungkinan bahan tambahan nonhalal dalam } \\
\text { produk impor olahan susu? }\end{array}$ & 39 & 22 & 39 \\
\hline $\begin{array}{l}\text { Apakah semua produk olahan susu yang mengandung gelatin diragukan } \\
\text { status kehalalannya? }\end{array}$ & 20 & 66 & 14 \\
\hline Pengetahuan mengenai kehalalan suatu produk lokal & 49 & 21 & 30 \\
\hline Apakah buah yang mengandung alkohol seperti durian diharamkan? & 07 & 11 & 82 \\
\hline Apakah tape termasuk kategori makanan halal? & 82 & 16 & 02 \\
\hline Apakah air nira (lahang) termasuk kategori makanan halal? & 59 & 36 & 05 \\
\hline Pengetahuan mengenai halal dalam segi kesehatan & 64 & 23 & 13 \\
\hline $\begin{array}{l}\text { Apakah semua obat-obatan dan suplemen yang mengandung gelatin } \\
\text { diharamkan? }\end{array}$ & 9 & 59 & 32 \\
\hline Apakah penggunaan alkohol dalam pengobatan darurat dibolehkan? & 87 & 11 & 2 \\
\hline Apakah mengonsumsi daging babi dapat menyebabkan berbagai penyakit? & 95 & 0 & 5 \\
\hline Pengetahuan mengenai halal dalam segi hukum & 56 & 30 & 14 \\
\hline $\begin{array}{l}\text { Apakah MUI (Majelis Ulama Indonesia) merupakan lembaga satu-satunya } \\
\text { yang memberikan sertifikasi halal bagi produk impor? }\end{array}$ & 81 & 14 & 5 \\
\hline Apakah ada peraturan yang mengatur mengenai produk halal di Indonesia & 87 & 11 & 2 \\
\hline $\begin{array}{l}\text { Apakah Undang-Undang No.8 tahun } 1999 \text { tentang perlindungan konsumen } \\
\text { sudah mengatur secara keseluruhan mengenai produk halal? }\end{array}$ & 11 & 75 & 14 \\
\hline $\begin{array}{l}\text { Menurut anda apakah di Indonesia masih banyak barang impor yang haram } \\
\text { dan diragukan kehalalannya (tidak mencantumkan logo/sertifikasi halal oleh } \\
\text { lembaga resmi di Indonesia? }\end{array}$ & 89 & 9 & 2 \\
\hline $\begin{array}{l}\text { Apakah semua produk makan impor yang dijual di pasaran sudah pasti lulus } \\
\text { uji halal oleh MUI? }\end{array}$ & 11 & 39 & 50 \\
\hline Pengetahuan mengenai halal dalam segi teknologi dan informasi & 53 & 31 & 16 \\
\hline Apakah ada aplikasi yang dapat mengecek sertifikasi halal sebuah produk? & 23 & 59 & 18 \\
\hline $\begin{array}{l}\text { Apakah masyarakat dapat memberikan pengaduan atau bertanya kepada } \\
\text { LPPOM MUI mengenai kehalalan suatu produk? }\end{array}$ & 80 & 15 & 5 \\
\hline $\begin{array}{l}\text { Apakah dengan adanya logo halal dapat membantu mengidentifikasi } \\
\text { kehalalan suatu produk impor? }\end{array}$ & 50 & 36 & 14 \\
\hline $\begin{array}{l}\text { Apakah pencantuman komposisi bahan yang dipakai suatu produk dapat } \\
\text { membantu mengidentifikasi kehalalan produk impor? }\end{array}$ & 62 & 11 & 27 \\
\hline
\end{tabular}

bagi siswa MA Persis 24 Rancekek Bandung dapat dilihat pada Gambar 1.

Terakhir, sosialisasi dilakukan dengan menggunakan metode yang kedua, yaitu metode latihan simulasi. Latihan simulasi ini dipandu oleh para fasilitator yang berasal dari mahasiswa yang sedang melakukan KKN. Latihan simulasi dilakukan dengan menggunakan smartphone yang sebelumnya telah terinstal aplikasi halal
MUI sebagai sarana untuk mengetahui apakah suatu produk telah tersertifikasi halal atau belum. Fasilitator memberikan bahan latihan simulasi berupa beberapa kemasan produk kepada siswa peserta sosialisasi untuk mengecek kehalalannya dengan menggunakan aplikasi halal MUI. Contoh tampilan aplikasi halal MUI dapat dilihat pada Gambar 2. 


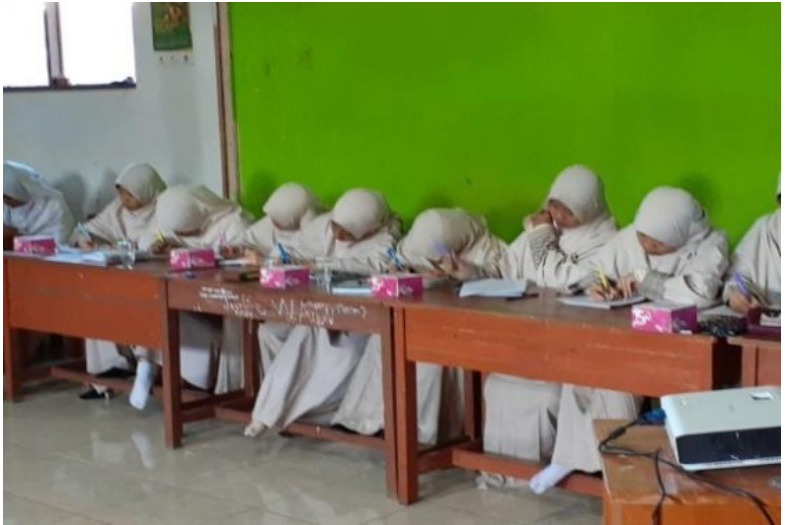

a

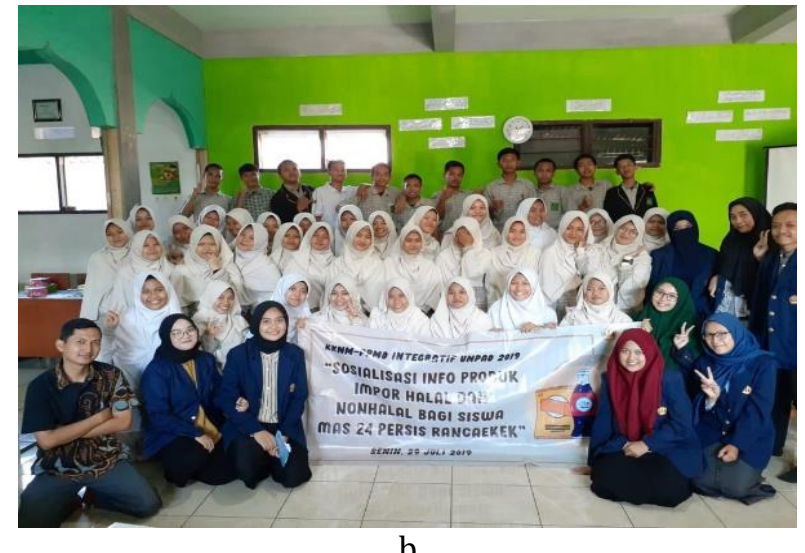

b

Gambar 1 a) Pelaksanaan kegiatan sosialisasi dan b) peserta dan panitia kegiatan sosialisasi.

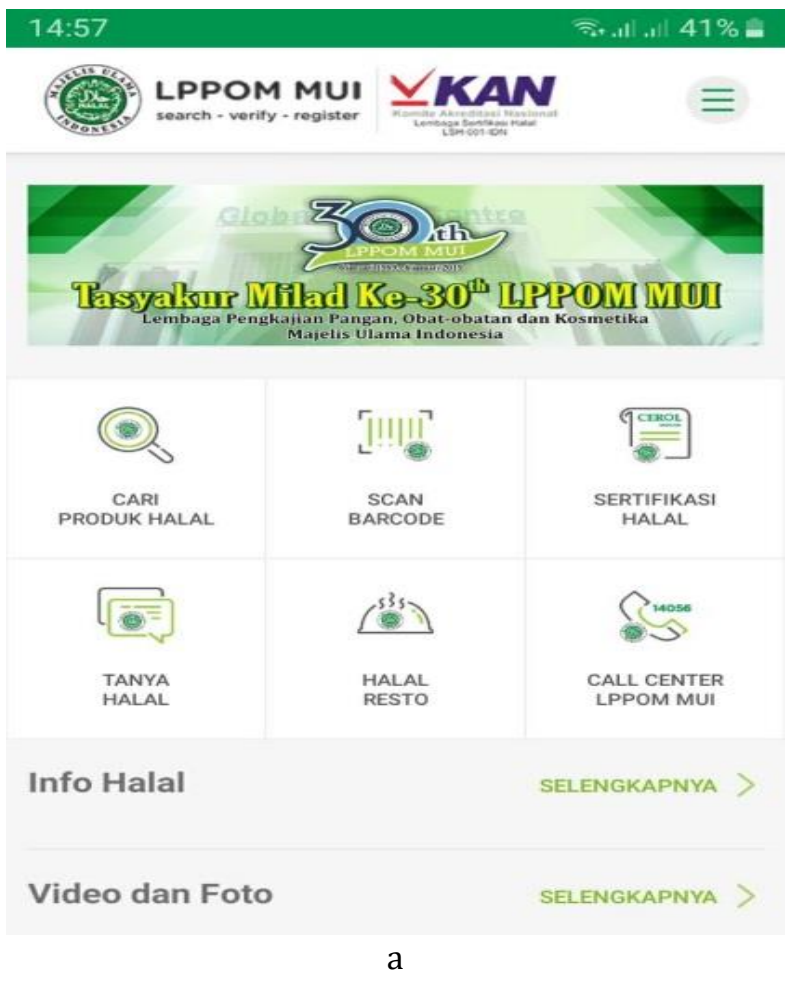

15:01
Cari Berdasarkan Merk Produk
Masukan Kata Kunci
KATEGORI PRoDuk
Meat and Processed Meat Products (Daging $>$
Fish and Processed Fish Products (Ikan dan
Produk Ikan Olahan)
Milk and Dairy Products (Susu dan Produk
Susu Olahan)
Infant/Toddler Milk and Food (Susu dan
Makanan Bayi/Balita)
Egg and Processed Egg Products (Telur dan
Produk Telur Olahan)
Plant and Processed Plant Products
(Tumbuhan dan Produk Tumbuhan Olahan)

Gambar 2 a dan b) Aplikasi halal MUI.

\section{Tahapan Post-test}

Setelah kegiatan sosialisasi dilakukan, selanjutnya siswa peserta pelatihan diberikan posttest dengan tujuan untuk mengetahui bagaimana pengaruh kegiatan sosialisasi yang telah dilakukan terhadap pengetahuan mereka, khususnya terkait produk impor. Kegiatan post-test difasilitasi oleh para mahasiswa KKN yang berperan sebagai fasilitator kegiatan sosialisasi. Materi pertanyaan post-test sama dengan pre-test. Begitu pula dengan instruksi pengerjaan dan waktu yang diberikan untuk mengisi kuesioner post-test semuanya sama dengan pelaksanaan pre-test. Adapun hasil dari kegiatan post-test yang dilakukan terhadap siswa peserta pelatihan sebagaimana tercermin dalam Tabel 2.

\section{Analisis Hasil}

Berdasarkan data hasil pre-test dan post-test sebagaimana tercermin pada Tabel 1 dan 2, dapat dimaknai seperti berikut.

\section{- Pengetahuan mengenai halal dalam segi agama}

Berdasarkan hasil pre-test dan post-test yang dilakukan sebagaimana ditunjukan dalam Tabel 1, dapat dilihat bahwa secara umum pengetahuan siswa MA Persis 24 Rancaekek terkait halal sudah baik. Hal ini terlihat dari persentase pertanyaan yang dijawab secara benar oleh siswa sudah mencapai lebih dari $60 \%$ pada pre-test dan peningkatannya tidak terlalu signifikan pada posttest. Tentunya, sebagai sekolah yang berbasis 
Tabel 2 Hasil post-test

\begin{tabular}{|c|c|c|c|}
\hline \multirow[b]{2}{*}{ Pertanyaan dan pernyataan } & \multicolumn{3}{|c|}{ Post-test } \\
\hline & $\begin{array}{c}\text { Ya } \\
(\%)\end{array}$ & $\begin{array}{l}\text { Ragu- } \\
\text { ragu }(\%)\end{array}$ & $\begin{array}{c}\text { Tidak } \\
(\%)\end{array}$ \\
\hline Pengetahuan mengenai halal dalam segi agama & 63 & 2 & 35 \\
\hline $\begin{array}{l}\text { Apakah di dalam QS. Al-Baqarah: } 168 \text { menjelaskan tentang perintah Allah } \\
\text { untuk mengonsumsi makanan halal dan baik? }\end{array}$ & $\begin{array}{r}10 \\
0\end{array}$ & 0 & 0 \\
\hline $\begin{array}{l}\text { Apakah semua produk yang tidak mengandung babi sudah pasti kehalalannya } \\
\text { dalam pandangan Islam? }\end{array}$ & 25 & 5 & 70 \\
\hline Pengetahuan mengenai kehalalan suatu produk impor & 89 & 4 & 7 \\
\hline $\begin{array}{l}\text { Apakah anda tahu ada banyak produk impor yang mengandung unsur turunan } \\
\text { dari babi? }\end{array}$ & 84 & 5 & 11 \\
\hline $\begin{array}{l}\text { Apakah anda mengetahui daging impor yang ASUH (Aman, sehat, utuh, dan } \\
\text { halal)? }\end{array}$ & $\begin{array}{r}10 \\
0\end{array}$ & 0 & 0 \\
\hline Apakah anda dapat membedakan antara daging impor yang halal dan haram? & 93 & 7 & 0 \\
\hline $\begin{array}{l}\text { Apakah anda tahu adanya kemungkinan bahan tambahan nonhalal dalam } \\
\text { produk impor olahan susu? }\end{array}$ & 91 & 2 & 7 \\
\hline $\begin{array}{l}\text { Apakah semua produk olahan susu yang mengandung gelatin diragukan status } \\
\text { kehalalannya? }\end{array}$ & 75 & 9 & 16 \\
\hline Pengetahuan mengenai kehalalan suatu produk lokal & 61 & 7 & 32 \\
\hline Apakah buah yang mengandung alkohol seperti durian diharamkan? & 5 & $5 \%$ & 90 \\
\hline Apakah tape termasuk kategori makanan halal? & 93 & 7 & 0 \\
\hline Apakah air nira (lahang) termasuk kategori makanan halal? & 84 & 9 & 7 \\
\hline Pengetahuan mengenai halal dalam segi kesehatan & 77 & 4 & 19 \\
\hline $\begin{array}{l}\text { Apakah semua obat-obatan dan suplemen yang mengandung gelatin } \\
\text { diharamkan? }\end{array}$ & 43 & 9 & 48 \\
\hline Apakah penggunaan alkohol dalam pengobatan darurat dibolehkan? & 93 & 2 & 5 \\
\hline Apakah mengonsumsi daging babi dapat menyebabkan berbagai penyakit? & 95 & 0 & 5 \\
\hline Pengetahuan mengenai halal dalam segi hukum & 80 & 4 & 16 \\
\hline $\begin{array}{l}\text { Apakah MUI (Majelis Ulama Indonesia) merupakan lembaga satu-satunya yang } \\
\text { memberikan sertifikasi halal bagi produk impor? }\end{array}$ & 73 & 0 & 27 \\
\hline Apakah ada peraturan yang mengatur mengenai produk halal di Indonesia & 90 & 5 & 5 \\
\hline $\begin{array}{l}\text { Apakah Undang-Undang No.8 tahun } 1999 \text { tentang perlindungan konsumen } \\
\text { sudah mengatur secara keseluruhan mengenai produk halal? }\end{array}$ & 84 & 0 & 16 \\
\hline $\begin{array}{l}\text { Menurut anda apakah di Indonesia masih banyak barang impor yang haram } \\
\text { dan diragukan kehalalannya (tidak mencantumkan logo/sertifikasi halal oleh } \\
\text { lembaga resmi di Indonesia? }\end{array}$ & 84 & 9 & 7 \\
\hline $\begin{array}{l}\text { Apakah semua produk makan impor yang dijual di pasaran sudah pasti lulus } \\
\text { uji halal oleh MUI? }\end{array}$ & 68 & 7 & 25 \\
\hline Pengetahuan mengenai halal dalam segi teknologi dan informasi & 95 & 1 & 4 \\
\hline Apakah ada aplikasi yang dapat mengecek sertifikasi halal sebuah produk? & $\begin{array}{r}10 \\
0\end{array}$ & 0 & 0 \\
\hline Apakah masyarakat dapat memberikan pengaduan atau bertanya kepada & 10 & 0 & 0 \\
\hline LPPOM MUI mengenai kehalalan suatu produk? & 0 & & \\
\hline $\begin{array}{l}\text { Apakah dengan adanya logo halal dapat membantu mengidentifikasi kehalalan } \\
\text { suatu produk impor? }\end{array}$ & 93 & 0 & 7 \\
\hline $\begin{array}{l}\text { Apakah pencantuman komposisi bahan yang dipakai suatu produk dapat } \\
\text { membantu mengidentifikasi kehalalan produk impor? }\end{array}$ & 87 & 2 & 11 \\
\hline
\end{tabular}

keislaman di bawah Kementerian Agama RI, sudah seyogyanya apabila pengetahuan dasar siswa tentang halal dari segi agama sudah baik. Pada pertanyaan pertama tentang dasar hukum halal dalam Al-Quran, lebih dari 90\% siswa menjawab dengan benar sebelum sosialisasi dilakukan. Kemudian, pada pertanyaan kedua pun mayoritas siswa sudah mengetahui bahwa ketika suatu produk tidak mengandung babi, bukan berarti produk tersebut sudah pasti halal karena syarat dari kehalalan produk bukan hanya sekedar mengandung babi atau tidak, namun juga banyak aspek lainnya.

\section{- Pengetahuan mengenai kehalalan suatu produk impor}

Berbeda dengan sebelumnya, kategori pengetahuan siswa MA Persis 24 Rancaekek mengenai 
kehalalan suatu produk impor meningkat dengan sangat signifikan pada sebelum dan setelah sosialisasi dilakukan. Dari hasil pre-test yang dilakukan, secara umum persentase siswa yang menjawab pertanyaan dengan benar masih rendah, yakni di bawah 30\%. Artinya, sebelum dilakukan sosialisasi, masih banyak siswa yang tidak tahu mengenai kehalalan produk impor. Namun, setelah dilakukan sosialisasi, secara umum persentase siswa yang menjawab pertanyaan dengan benar kemudian meningkat menjadi $76,8 \%$. Dari kelima pertanyaan dalam kategori ini, peningkatan paling signifikan terjadi pada pertannyaan nomor 4, 5, dan 6. Artinya pengetahuan siswa mengenai daging impor yang ASUH (Aman, Sehat, Utuh, dan Halal), cara membedakan daging impor yang halal dan nonhalal, dan kemungkinan adanya bahan tambahan nonhalal dalam produk impor olahan susu mengalami peningkatan setelah dilakukannya sosialisasi. Sedangkan, pertanyaan nomor 3 tidak mengalami peningkatan yang terlalu signifikan karena dari hasil pre-test yang dilakukan 64\% siswa mampu menjawab pertanyaan dengan benar. Artinya, sebelum sosialisasi dilakukan secara umum pengetahuan mereka akan adanya produk impor yang mengandung unsur turunan babi sudah cukup baik. Meskipun tidak signifikan, namun setelah dilakukan post-test, persentase siswa yang menjawab dengan benar kemudian meningkat sebesar $20 \%$ menjadi $84 \%$. Lain pula halnya dengan pertanyaan nomor 7 terkait kandungan gelatin dalam produk olahan susu, di mana hasil dari pre-test yang dilakukan $14 \%$ siswa menjawab pertanyaan dengan benar dan dari hasil post-test yang dilakukan $16 \%$ siswa menjawab pertanyaan dengan benar. Artinya, hanya terjadi sedikit peningkatan antara sebelum dan setelah sosialisasi sehingga ke depannya pengetahuan terkait hal ini masih perlu ditingkatkan kembali.

\section{- Pengetahuan mengenai kehalalan suatu produk lokal}

Pengetahuan siswa dalam kategori kehalalan suatu produk lokal secara umum meningkat antara sebelum dan setelah dilakukan sosialisasi, meskipun tidak terlalu signifikan. Hal ini dapat terlihat dari persentase siswa yang menjawab pertanyaan dengan benar pada saat pre-test telah mencapai $74 \%$, yang menunjukan bahwa pengetahuan mereka terkait kehalalan suatu produk lokal sudah baik. Persentase tersebut kemudian meningkat menjadi $89 \%$ pada saat post-test, yang artinya jumlah siswa yang mampu menjawab dengan benar bertambah setelah dilakukannya sosialisasi. Diantara ketiga pertanyaan dalam kategori ini, dua diantaranya, yakni "Apakah buah yang mengandung alkohol seperti durian diharamkan?" dan "Apakah tape termasuk kategori makanan halal?" dapat dijawab dengan baik dari sebelum sosialisasi dilakukan, terlihat dari hasil pre-test di mana persentase siswa yang menjawab benar adalah sebesar 82\%. Sedangkan, untuk pertanyaan ketiga, yakni "Apakah air nira (lahang) termasuk kategori makanan halal?", persentase siswa yang menjawab pertanyaan dengan benar pada saat pre-test hanya sebesar 59\%. Artinya sebelum dilakukan sosialisasi, belum banyak siswa yang mengetahui status kehalalan dari air nira ini. Namun, setelah dilakukan sosialisasi, siswa yang mengetahui status kehalalan dari air nira ini meningkat menjadi $84 \%$, yang terlihat dari post-test. Artinya, siswa yang awalnya tidak tahu, setelah menerima sosialisasi, menjadi tahu bahwa air nira ini termasuk makanan yang halal.

\section{- Pengetahuan mengenai halal dalam segi kesehatan}

Secara umum, peningkatan pengetahuan siswa MA Persis 24 Rancaekek mengenai halal dalam segi kesehatan setelah dilakukan post-test tidak terlalu signifikan. Adapun dari tiga pertanyaan yang diajukan, pertanyaan pertama mengenai apakah kandungan gelatin dalam semua obat-obatan dan suplemen termasuk haram, hanya $32 \%$ yang menjawab tidak, di mana ini merupakan jawaban yang tepat. Setelah dilakukan pre-test, persentase siswa yang menjawab dengan tepat meningkat menjadi $48 \%$. Pada pertanyaan kedua, yaitu apakah penggunaan alkohol dalam pengobatan darurat dibolehkan, hasil dari pre-test sudah cukup tinggi sebesar $87 \%$ dan mengalami peningkatan menjadi 93\%. Selanjutnya, yaitu menanyakan tentang apakah konsumsi daging babi dapat menyebabkan berbagai penyakit, sebanyak 95\% sudah menjawab dengan tepat dan tidak ada peningkatan pada hasil post-test.

Peningkatan yang tidak terlalu signifikan dapat dikaitkan dengan adanya pengetahuan yang sudah relatif tinggi mengenai halal dalam segi agama oleh siswa MA Persis 24, terutama pada pertanyaan kedua dan ketiga. Akan tetapi, pada pertanyaan pertama mengenai gelatin, siswa belum banyak yang memahami mengenai apa itu gelatin dan status kehalalannya dalam obat-obatan dan suplemen. Meskipun begitu, 
secara umum, pengetahuan dasar mengenai halal dalam segi kesehatan telah dimiliki oleh siswa MA Persis 24 Rancaekek secara baik.

\section{- Pengetahuan mengenai halal dalam segi hukum}

Dari data yang didapat, secara umum juga terjadi peningkatan pengetahuan siswa MA Persis 24 Rancaekek mengenai halal dalam segi hukum yakni dari 56\% menjadi 80\%. Partisipan mulai mengetahui tentang perubahan kewenangan lembaga sertifikasi halal di Indonesia dari MUI kepada BPJPH. Mereka mengetahui bahwa sudah ada peraturan yang mengatur tentang produk halal di Indonesia, yaitu sebanyak 90\% siswa pada hasil post-test dari hasil pre-test sebanyak 87\%. Meskipun begitu, mereka juga belum memahami bahwa UndangUndang No. 8 Tahun 1999 tentang Perlindungan Konsumen belum secara menyeluruh mengatur mengenai produk halal, yang mana di Indonesia sendiri masih banyak tersebar produk impor haram ataupun yang diragukan kehalalannya karena tidak memiliki logo/sertifikat halal oleh lembaga resmi di Indonesia. Padahal produkproduk yang berada di pasaran belum tentu lulus uji halal oleh MUI secara pasti. Hal ini dapat menjadi evaluasi untuk penelitian selanjutnya. Begitu pula kehadiran dan implementasi UU No. 33 Tahun 2014 tentang Jaminan Produk Halal masih sangat asing bagi siswa MA Persis 24 Rancaekek.

\section{- Pengetahuan mengenai halal dalam segi teknologi dan informasi}

Telah terjadi peningkatan yang sangat signifikan pada pengetahuan siswa MA Persis 24 Rancaekek mengenai halal dalam segi teknologi dan informasi. Dari keempat pertanyaan yang diajukan, mayoritas siswa yakni sebanyak 59\% menjawab ragu-ragu dan $18 \%$ nya menjawab tidak pada pertanyaan pertama. Artinya, mayoritas siswa MA Persis 24 saat itu belum mengetahui bahwa sudah ada aplikasi untuk mengecek sertifikasi halal suatu produk. Kemudian setelah dilakukan sosialisasi sebagaimana terlihat dari hasil post-test, sebesar 100\% siswa telah mengetahuinya, yaitu aplikasi "Halal MUI". Begitu pula dengan pertanyaan kedua, telah terjadi peningkatan sebesar $20 \%$ yakni dari $80 \%$ menjadi $100 \%$ siswa yang menjawab dengan tepat. Pada pertanyaan selanjutnya, dapat diketahui bahwa siswa MA Persis 24 masih relatif kurang memiliki pengetahuan terkait manfaat dan pentingnya logo halal pada suatu produk, terutama produk impor. Terlihat pada hasil pretest bahwa hanya $50 \%$ siswa yang menjawab dengan tepat sedangkan sisanya baru memahami setelah dilakukan pre-test yang hasilnya meningkat menjadi 93\%. Pertanyaan terakhir terkait komposisi bahan, juga mengalami peningkatan dari $62 \%$ menjadi $87 \%$. Dalam sosialisasi tersebut, dapat dilihat bahwa meskipun siswa MA Persis 24 Rancaekek memiliki pengetahuan agama yang cukup tinggi tentang kehalalan pada sub-poin A, namun pada segi teknologi dan informasi belum banyak siswa yang mengetahuinya. Hal ini dapat dijelaskan karena kurangnya informasi dan sosialisasi yang didapatkan oleh mereka terkait sertifikasi halal, termasuk di dalamnya aplikasi yang dapat diakses, layanan LPPOM MUI, logo halal, serta komposisi produk yang dapat dijadikan acuan dalam mengidentifikasi kehalalan suatu produk.

Selanjutnya dilakukan Paired Sample Test untuk mengukur pengaruh pemberian sosialisasi terhadap pengetahuan siswa MA Persis 24 Rancaekek terkait produk impor halal dan nonhalal, maka didapatkanlah hasil seperti pada Tabel 3, 4, dan 5.

Hipotesis, $\mathrm{H}_{0}$ : Rata-rata nilai post-test siswa MA Persis 24 Rancaekek mengenai produk impor halal dan nonhalal tidak lebih tinggi daripada nilai pre-test. $\mathrm{H}_{1}$ : Rata-rata nilai post-test siswa MA Persis 24 Rancaekek mengenai produk impor halal dan nonhalal lebih tinggi daripada nilai pretest. Statistik uji; rata-rata nilai pre-test: $\mathrm{M}=11,8182, \mathrm{SD}=2,45208$. Rata-rata nilai post-test : $\mathrm{M}=17,2500, \mathrm{SD}=1,91839 . \mathrm{t}(43)=-15,040 ; \mathrm{p}=$ $0.000 ; \alpha=0,05$. Kriteria uji, tolak $\mathrm{H}_{0}$ jika $\mathrm{t} \geq \mathrm{t}$ table atau $\mathrm{p} \leq \alpha$. $\mathrm{p}$-value $=0,00<\alpha=0,05$, maka, $\mathrm{H}_{0}$ ditolak. Hasil: 1) Hasil pre-test yaitu didapatkan rata-rata (mean) sebesar $=11,8182$ dan standar deviasi (SD) sebesar $=2,45208 ; 2$ ) Hasil post-test, yaitu didapatkan rata-rata (mean) sebesar = 17,2500 dan standar deviasi (SD) sebesar = 1,91839; dan 3) Dari hasil uji t, didapatkan nilai signifikan 0,000. Nilai signifikan kurang dari derajat kepercayaan, yaitu 0,05.

Berdasarkan hasil tersebut dapat dilihat bahwa dari 22 soal pre-test dan post-test untuk mengukur sejauh mana pengetahuan siswa MA Persis 24 Rancaekek terhadap kehalalan produkproduk impor, didapatkanlah hasil berupa ratarata nilai pre-test sebesar 11,8 . Artinya sebelum melakukan sosialisasi, jumlah soal mengenai produk impor halal yang dapat yang dijawab benar hanya sebesar kurang lebih 53\% atau setengah dari jumlah soal yang diberikan. Hal ini menunjukan bahwa meskipun merupakan 
Tabel 3 Hasil olahan IBM SPSS versi 21 paired samples statistics

\begin{tabular}{rcccc}
\hline & Mean & $\mathrm{N}$ & Std. Deviation & Std.Error Mean \\
\hline Pair 1 VAR00001 & 11.8182 & 44 & 2.45208 & .36966 \\
VAR00002 & 17.2500 & 44 & 1.91839 & .28921 \\
\hline
\end{tabular}

Tabel 4 Hasil olahan IBM SPSS versi 21 paired samples correlations

\begin{tabular}{cccc}
\hline & $\mathrm{N}$ & Correlation & Sig. \\
\hline Pair VAR00001 \&VAR00002 & 44 & .420 & .005 \\
\hline
\end{tabular}

Tabel 5 Hasil olahan IBM SPSS versi 21 paired samples test

\begin{tabular}{|c|c|c|c|c|c|c|c|c|}
\hline & \multicolumn{5}{|c|}{ Paired differences } & \multirow{3}{*}{$\mathrm{t}$} & \multirow{3}{*}{$\mathrm{df}$} & \multirow{3}{*}{$\begin{array}{l}\text { Sig. }(2- \\
\text { tailed })\end{array}$} \\
\hline & \multirow[t]{2}{*}{ Mean } & \multirow[t]{2}{*}{$\begin{array}{c}\text { Std. } \\
\text { deviation }\end{array}$} & \multirow[t]{2}{*}{$\begin{array}{l}\text { Std. error } \\
\text { mean }\end{array}$} & \multicolumn{2}{|c|}{$\begin{array}{c}\text { 95\% confidence } \\
\text { interval of the } \\
\text { difference }\end{array}$} & & & \\
\hline & & & & Lower & Upper & & & \\
\hline $\begin{array}{l}\text { Pair } 1 \text { VAR00001- } \\
\text { VAR00002 }\end{array}$ & -5.43182 & 2.39571 & .36117 & -6.16018 & -4.70346 & -15.040 & 43 & .000 \\
\hline
\end{tabular}

sekolah yang berbasis Islam, namun pengetahuan siswa MA Persis 24 Rancaekek mengenai kehalalan produk impor masih kurang atau belum begitu mengetahui bagaimana cara membedakan produk impor yang halal dan nonhalal. Hal ini menguatkan alasan mengenai pentingnya pemberian sosialisasi terkait kehalalan produk impor di kalangan milenial.

Setelah mendapatkan tolak ukur tingkat pengetahuan siswa MA Persis 24 Rancaekek terkait kehalalan produk halal, dilakukanlah sosialisasi sebagai upaya untuk meningkatkan pengetahuan siswa terkait produk impor halal dan nonhalal. Setelah sosialisasi selesai, dilakukanlah post-test sebagai tolak ukur keberhasilan sosialisasi ini. Dengan melihat rata-rata nilai post-test siswa MA Persis 24 Rancaekek mengenai sosialisasi produk impor halal dan nonhlal, lebih tinggi daripada nilai pre-test, yakni sebesar 17,2. Hal ini menunjukan bahwa dalam post-test ini jumlah soal yang dijawab benar oleh siswa MA Persis 24 Rancaekek meningkat menjadi $78 \%$ dari sebelumnya yang hanya sebesar $53 \%$. Dengan demikian, maka hipotesis $\mathrm{H}_{0}$ ditolak, atau dengan kata lain sosialisasi yang dilakukan terbukti memberikan pengaruh yang signifikan terhadap pengetahuan siswa MA Persis 24 Rancaekek terhadap kehalalan produk impor. Hal ini sesuai dengan harapan output dari kegiatan PPM, yakni meningkatnya pengetahuan siswa MA Persis 24 Rancaekek mengenai kehalalan produk impor.

\section{Kendala dan Dampak Pelaksanaan Kegiatan}

Ada beberapa kendala yang dihadapi dalam pelaksanaan evaluasi kegiatan sosialisasi. Per- tama, variasi dan jumlah peserta sosialisasi yang kurang bisa dikontrol. Hal ini disebabkan karena jumlah peserta sangat tergantung dari kesiapan dan izin yang diberikan oleh pihak sekolah sebagai pihak pemberi izin kegiatan. Selain itu, kendala lainnya terkait dengan adanya beberapa kelemahan dari penggunaan metode sosialisasi yang digunakan itu sendiri. Metode seminar berupa ceramah terkendala masalah kapasitas ruangan dan segala fasilitas pendukungnya begitu pula dengan metode latihan simulasi dengan menggunakan aplikasi smartphone. Metode latihan simulasi sangat tergantung pada dukungan dan ketersediaan alat dan infrastruktur seperti gadget dan jaringan wifi agar dalam pelaksanaannya tidak memiliki gangguan yang berarti. Dampak dari evaluasi kegiatan sosialisasi ini yakni dapat diketahui kelebihan dan kekurangan masing-masing metode yang digunakan dalam kegiatan sosialisasi. Sehingga kendala ini diharapkan dapat dikurangi bahkan diatasi pada pelaksanaan sosialisasi berikutnya.

\section{Upaya Keberlanjutan Kegiatan}

Keberhasilan sosialisasi halal dalam rangka untuk meningkatkan pengetahuan masyarakat ditentukan oleh sinergitas semua pihak (stakeholders) yang terlibat di dalamnya seperti: pelaku usaha, konsumen, pemerintah, dan masyarakat secara luas. Pada kegiatan PPM yang telah kami lakukan tahun lalu, sosialisasi halal ditujukan kepada salah satu komponen dari produsen halal yakni UMKM yang ada di Jatinangor. Dalam kegiatan tersebut, ditemukan bahwa pemahaman UMKM di Jatinangor terhadap kewajiban sertifikasi halal masih relatif rendah. Akan tetapi, 
peningkatan pemahaman mereka berhasil dilakukan berkat dengan adanya sosialisasi dalam kegiatan tersebut (Akim et al. 2018). Pada tahun ini, kegiatan sosialisasi kembali dilakukan namun kini berfokus pada konsumen produk impor. Pemilihan siswa MA sendiri didasarkan pada pertimbangan kaum milenial sebagai representasi dari konsumen produk impor yang potensial. Dengan adanya sosialisasi tersebut diharapkan munculnya kesadaran dan keinginan dari para siswa untuk lebih memahami produk impor halal dan nonhalal yang mana di antaranya dapat dilakukan dengan memanfaatkan ponsel dan internet. Apalagi saat ini LPPOM MUI pun memiliki layanan masyarakat untuk bertanya, menyediakan fitur pencarian produk halal di situs resminya, dan memiliki aplikasi bernama halal MUI untuk memudahkan masyarakat, khususnya milenial dalam mengecek suatu produk tertentu seperti makanan, minuman, obat, dan kosmetika. Dengan demikian, para siswa akan terhindar dari bahaya produk haram yang dilarang dalam syariat Islam dan berbahaya bagi kesehatan.

Selanjutnya sosialisasi tentang kehalalan produk impor dapat juga diperluas cakupannya, baik sasaran maupun wilayahnya. Sasaran ini di antaranya bisa diperluas menjadi bukan hanya siswa MA, namun juga pelajar sekolah umum seperti SMA/SMK dan kalangan mahasiswa. Dari sisi wilayah, cakupannya dapat diperluas menjadi bukan hanya di Rancaekek Kabupaten Bandung, melainkan juga Kota Bandung, Jawa Barat, atau bahkan nasional. Dengan adanya perluasan sasaran dan wilayah dalam sosialisasi produk impor halal dan nonhalal ini, maka pengetahuan produsen dan konsumen di berbagai daerah terhadap kehalalan produk impor akan semakin meningkat. Dampaknya adalah kekhawatiran konsumen akan ancaman produk impor nonhalal akan menurun dengan semakin banyaknya produsen luar negeri yang menawarkan produk impor dengan sertifikasi halal.

Rencana keberlanjutan program PPM selanjutnya yakni "Sosialisasi Produk Impor Halal dan Nonhalal terhadap Mahasiswa di Jatinangor Sumedang". Dengan adanya sosialiasi terhadap kalangan mahasiswa diharapkan kegiatan sosialisasi halal dapat lebih menyentuh berbagai lapisan masyarakat karena mengikutsertakan berbagai konsumen produk impor secara lebih beragam dan luas dalam kegiatan sosialisasi tersebut.

\section{SIMPULAN}

Berdasarkan hasil evaluasi pelaksanaan kegiatan sosialisasi produk impor halal dan nonhalal bagi siswa MA Persis 24 Rancaekek diketahui bahwa kegiatan sosialiasi yang telah dilakukan berhasil meningkatkan pengetahuan siswa MA Persis Rancaekek terkait kehalalan suatu produk impor yang beredar di masyarakat. Hal ini tercermin dari peningkatan nilai hasil tes yang dilakukan terhadap siswa yang peserta sosialisasi. Hasil pre-test menunjukan angkat rata-rata sebesar 11,81, kemudian setelah dilakukan sosialisasi angkat rata-rata dalam post test meningkat menjadi 17,25. Dengan demikian, untuk meningkatkan kesadaran dan pengetahuan siswa, diperlukan adanya upaya kegiatan sosialisasi sejenis yang bersifat masif dan terarah kepada siswa-siswi sekolah lainnya di wilayah Bandung dan sekitarnya. Selain itu, untuk mendukung terlaksananya kegiatan-kegiatan tersebut, bantuan atau hibah dana juga sangat dibutuhkan baik dari pemerintah ataupun pihakpihak lainnya agar kegiatan sosialisasi dapat dilaksanakan secara berkelanjutan dan menyisir berbagai kalangan masyarakat lainnya yang lebih luas.

\section{UCAPAN TERIMA KASIH}

Ucapan terima kasih setinggi-tingginya disampaikan kepada institusi kami Universitas Padjadjaran, yang telah memberikan dukungan moril dan materil sehingga kegiatan KKNMPPMD Integratif Unpad 2019 ini dapat terselenggara dengan baik. Selain itu, ucapan terima kasih juga kami sampaikan kepada para mahasiswa yang terlibat dalam program KKNMPPMD Integratif 2019 di Kecamatan Rancaekek yang telah banyak memberikan kontribusinya dalam kegiatan ini. Tak lupa, ucapan terima kasih juga kami sampaikan kepada pihak MA Persis 24 Rancaekek Bandung, yang telah berkenan memberikan izin untuk pelaksanaan KKNMPPMD Integratif Unpad, serta para siswa MA Persis 24 Rancaekek, yang telah bersedia menjadi partisipan dalam kegiatan sosialisasi ini.

\section{DAFTAR PUSTAKA}

Agrifood. 2018. Tidak Berlabel Halal, 11 Produk Makanan Impor Beredar di Pasaran. Retrieved 
Maret 20, 2020, from Agrifood: https://agrifood.id/tidak-berlabel-halal-11produk-makanan-impor-beredar-di-pasaran/

Akim, Konety N, Purnama C, Adilla MH. 2018. Pemahaman Usaha Mikro, Kecil, dan Menengah (UMKM) di Jatinangor Terhadap Kewajiban Sertifikasi Halal Pada Produk Makanan. Kumawula: Jurnal Pengabdian Kepada Masyarakat, 1(1), 31-49. https://doi.org/10.24198/kumawula.v1i1.19 258

Baharuddin K, Kassim NA, Nordin SK, Buyong SZ. 2015. Understanding the Halal Concept and the Importance of Information on Halal Food Business Needed by Potential Malaysian Entrepreneurs. International Journal of Academic Research in Business and Social Sciences. 5(2): 170-180. https://doi.org/ 10.6007/IJARBSS/v5-i2/1476

Berty TT. 2019. Jokowi: Indonesia Negara Muslim Terbesar, Modal Utama Diplomasi Internasional. Retrieved Maret 20, 2020, from Liputan6: https://www. liputan6.com/global/read/3930124/jokowiindonesia-negara-muslim-terbesar-modalutama-diplomasi-internasional

[BPS] Biro Pusat Statistik. 2018. Statistik Tematik: Profil Generasi Milenial Indonesia. Jakarta: Kementerian Pemberdayaan Perempuan dan Perlindungan Anak.

[BPOM] Badan Pengawas Obat dan Makanan. 2017. Penarikan Produk Mi Instan Asal Korea yang Mengandung Babi. [Internet]. [Diakses pada Maret 2020]. Tersedia pada: https://www. pom.go.id/new/view/more/ pers/374/PENARIKAN-PRODUK-MI-INSTANASAL-KOREA-YANG-MENGANDUNGBABI.html

Budiman R. 2019. Factors Influencing Purchase Intention of Halal Products in Pontianak City. Indonesian Journal of Halal Research. 1(2): 4648. https://doi.org/10.15575/ijhar.v1i2.4440

Hakim RN. 2019. Ma'ruf Heran Indonesia jadi Importir Produk Halal Terbesar di Dunia. Retrieved Maret 20, 2020, from Kompas: https://nasional.kompas.com/read/2019/12 /06/22184151/maruf-heran-indonesia-jadiimportir-produk-halal-terbesar-di-dunia

Handayani S. 2016. Waspadai Produk Impor Berlabel Halal Palsu. Retrieved Maret 20, 2020, from Republika: https://republika.co.id/berita/o3vfwa23/wa spadai-produk-impor-berlabel-halal-palsu

Hosanna MA, Nugroho SA. 2018. Pelaksanaan Undang-Undang Nomor 33 Tahun 2014 Tentang Jaminan Produk Halal Terhadap Pendaftaran Sertifikat Halal Pada Produk Makanan. Jurnal Hukum Adigama. 1(1): 1-24. https://doi.org/10.24912/adigama.v1i1.215 5

International Trade Centre. 2015. From Niche to Mainstream: Halal Goes Global. Geneva (CH): International Trade Centre.

Kementerian Agama. (2020). Data Umat Berdasar Jumlah Pemeluk Agama Menurut Agama. Retrieved Maret 20, 2020, from Kementerian Agama Republik Indonesia: http://data. kemenag.go.id/agamadashboard/statistik/u mat

Lada S, Tanakinjal GH, Amin H. 2009. Predicting intention to choose halal products using theory of reasoned action. International Journal of Islamic and Middle Eastern Finance and Management. 2(1): 66-76. https://doi. org/10.1108/17538390910946276

Nirwandar S. 2019. Tata Kelola Sertifikasi Halal di Asia Tengggara. (Amantjik FR \& Shalihah FA Interviewers)

Nusran M, Gunawan, Razak M, Numba S, Wekke IS. 2018. Halal Awareness on the Socialization of Halal Certification. In: IOP Confrence Series: Earth and Environmental Science. page: 1-7. https://doi.org/10.1088/17551315/175/1/012217

Ramadhan B. 2016. Petugas Temukan Makanan Impor tak Berlabel Halal Saat Sidak. Retrieved Maret 20, 2020, from Republika : https:// republika.co.id/berita/oijcap330/petugastemukan-makanan-impor-tak-berlabel-halalsaat-sidak

Ratanamaneichat C, Rakkarn S. 2013. Quality Assurance Development of Halal Food Products for Export to Indonesia. Procedia Social and Behavioral Sciences. 88: 134-141. https://doi.org/10.1016/j.sbspro.2013.08.48 8

Revin I, Suradi, Islamiyati. 2017. Perlindungan Hukum Bagi Konsumen Terhadap Adanya Pemalsuan Labelisasi Halal Pada Produk Pangan Impor. Diponegoro Law Journal. 6(2): $1-12$. 
Robin WA. 2004. Guidelines for the preparation of Halal food and goods for the muslim consumers. Putrajaya, Malaysia (MY): AmalMerge.

Salehudin I. 2010. Halal Literacy: A Concept Exploration and Measurement Validation. ASEAN Marketing Journal. 2(1): 1-12. https://doi.org/10.21002/amj.v2i1.1987
Yasid, Farhan F, Andriansyah Y. 2016. Factors Affecting Muslim Students Awareness of Halal Products in Yogyakarta, Indonesia. International Review of Management and Marketing, 6(S4), 27-31. 